\title{
Kontribusi Academic Self-Efficacy dan Iklim Sekolah terhadap Kepuasan Hidup Siswa SMA
}

\author{
(Academic Self-Efficacy and School Climate Contribution to High School \\ Student Life Satisfaction)
}

\author{
PUTI ANNISA UTARI, LUCIA R. M. ROYANTO, STEPHANIE YUANITA INDRASARI \\ Fakultas Psikologi, Universitas Indonesia \\ E-mail: puti.annisa@gmail.com
}

Diterima 4 April 2017, Disetujui 24 Agustus 2017

\begin{abstract}
Abstrak: Siswa remaja yang sebelumnya terbiasa bergantung kepada orang dewasa, diharapkan dapat beralih menjadi mandiri dan mulai memikirkan masa depannya. Jika mereka tidak memiliki kesiapan mental yang cukup untuk menghadapi tuntutan dari lingkungannya, dikhawatirkan dapat menimbulkan emosi-emosi negatif yang dapat berakibat pada munculnya masalah perilaku, seperti depresi dan kenakalan. Masalah perilaku tersebut jika tidak segera ditangani, akan beresiko pada buruknya perkembangan diri siswa. Siswa dikhawatirkan akan gagal menguasai kemampuan positif yang seharusnya dimiliki oleh orang dewasa, seperti kemampuan mengontrol emosi dan berperilaku secara bertanggung jawab. Mempertimbangkan bahwa siswa menghabiskan hampir seluruh waktunya di sekolah, maka sudah seharusnya lingkungan fisik dan lingkungan sosial di sekolah memiliki peran dalam membantu diri siswa untuk dapat melalui usia remaja dengan perkembangan diri yang positif. Oleh karena itu, penelitian ini mencoba menyelidiki seberapa besar kontribusi dari faktor-faktor yang berkaitan dengan hal akademis, yaitu academic self-efficacy dan iklim sekolah terhadap kepuasan hidup siswa. Penelitian ini menggunakan pendekatan kuantitatif dengan menggunakan kuesioner academic self-efficacy, iklim sekolah, dan kepuasan hidup siswa. Responden akhir yang diperoleh berjumlah 211 siswa kelas XII yang berasal dari SMAN 5, SMAN 6, dan SMAN 7 Depok. Data yang diperoleh dianalisa dengan uji regresi linear berganda. Hasil penelitian menunjukkan bahwa academic self-efficacy dan iklim sekolah memiliki kontribusi yang signifikan terhadap kepuasan hidup siswa, baik secara simultan dan parsial. Tidak ada perbedaan signifikan yang ditemukan dalam pengukuran kepuasan hidup antara responden perempuan dan laki-laki.
\end{abstract}

Kata kunci: kepuasan hidup; academic self-efficacy; iklim sekolah; siswa; remaja

\begin{abstract}
Teenage students who were previously accustomed to relying on adults, are expected to be independent and start thinking about their future. If they do not have enough mental readiness to deal with demands from their environment, it is feared that it can cause negative emotions that can result in the emergence of behavioral problems, such as depression and delinquency. These behavioral problems if not addressed immediately, will risk the poor development of students. Students are worried that they will fail to master the positive abilities that adults should have, such as the ability to control emotions and behave responsibly. Considering that students spend almost all of their time in school, the physical environment and social environment in schools should have a role in helping students to get through adolescence with positive self-development. Therefore, this study attempts to investigate the contribution of factors related to academic matters, namely academic self-efficacy and school climate on student life satisfaction. This study uses a quantitative approach using academic self-efficacy questionnaires, school climate, and student life satisfaction. The final respondents obtained were 211 class XII students from SMAN 5, SMAN 6, and SMAN 7 Depok. The data obtained were analyzed by multiple linear regression test. The results showed that academic self-efficacy and school climate had a significant contribution to student life satisfaction, both simultaneously and partially. No significant differences were found in the measurement of life satisfaction between female and male respondents.
\end{abstract}

Key words: life satisfaction; academic self-efficacy; school climate; student; adolescence 


\section{PENDAHULUAN}

Siswa SMA berada pada tahap perkembangan remaja, di mana masa remaja merupakan masa peralihan dari masa kanakkanak menuju masa dewasa. Masa remaja berada pada rentang antara usia 11 hingga 21 tahun. Pada masa peralihan ini siswa mengalami perkembangan yang mencakup aspek fisik, psikis, dan sosial yang pada prinsipnya diharapkan mengalami kematangan sebelum siswa memasuki usia dewasa (Thalib, 2010). Sebagai contoh, siswa pada usia remaja diharapkan dapat mulai mengembangkan kemandirian, tidak lagi bersikap kekanakan. Siswa juga diharapkan dapat menentukan profesi yang akan ditekuninya kelak serta mempelajari keterampilan yang menunjang profesinya tersebut. Jika tuntutan dari lingkungan tidak sesuai dengan kesiapan diri siswa untuk menerimanya, tidak jarang hal ini membuat emosi siswa menjadi tidak stabil (Thalib, 2010).

Rosenblum dan Lewis (dalam Santrock, 2007), mengemukakan bahwa siswa pada masa remaja cenderung moody dan mudah berubah emosinya. Hal ini sebenarnya merupakan hal yang normal, namun jika emosi negatif muncul secara intens, maka dapat menghasilkan masalah perilaku yang serius pada diri siswa, seperti depresi dan kenakalan perilaku (Santrock, 2007). Bongers, Koot, Van der Ende, dan Verhulst (dalam Santrock, 2007) menemukan bahwa kenakalan seperti kabur dari kelas, membolos, dan susah diatur, meningkat di usia remaja. Jika frekuensi terjadinya masalah seperti ini tinggi, hal ini dikhawatirkan dapat menghambat perkembangan positif pada diri siswa. Siswa dikhawatirkan akan sulit mencapai kematangan perkembangan yang dibutuhkan ketika memasuki usia dewasa. Saat memasuki usia dewasa, siswa bisa jadi masih belum mampu untuk mengontrol emosi, atau menunjukkan sikap antisosial seperti mengintimidasi orang lain, merusak alam, menyalahgunakan fasilitas umum, atau melakukan tindakan apapun yang mengabaikan kenyamanan hidup orang-orang di sekitarnya (Harradine, dkk., dalam Millie, 2009). Hal ini akan semakin menyulitkan siswa untuk beradaptasi dengan lingkungan sosialnya. Oleh karena itu, dibutuhkan suatu proteksi untuk siswa agar dapat mengatasi atau menghindari masalahmasalah perilaku tersebut.

Huebner, Suldo, dan Gilman (dalam Whitley, 2010), berargumen bahwa masalah perilaku pada siswa remaja umumnya dapat dihindari dengan memberikan perhatian pada pemenuhan kepuasan hidup siswa. Kepuasan hidup didefinisikan sebagai penilaian kognitif seseorang terhadap kehidupannya secara menyeluruh (Pavot, Diener, Colvin, \& Sandvik, dalam Danielsen, Samdal, Hetland, \& Wold, 2009). Kepuasan hidup menggambarkan bagaimana evaluasi seseorang mengenai kondisi dirinya pada saat ini dengan kondisi ideal yang dia harapkan (Diener, 1994). Hal ini menunjukkan bahwa kepuasan hidup bersifat subjektif atau berbeda standar dan penilaiannya bagi setiap orang. Kepuasan hidup bersifat cukup stabil dalam jangka waktu yang lama, tetapi dapat berubah jika kondisi seseorang mengalami perubahan yang drastis (Diener, 1994), misalnya pernikahan atau kematian orang terdekat.

Kepuasan hidup adalah konstruk psikologi yang mengevaluasi kehidupan seseorang secara menyeluruh sehingga dapat dilihat secara global maupun secara spesifik berdasarkan ranah-ranah kehidupan yang ada (Huebner, 2004). Bagi siswa, ranah kehidupan yang penting bagi dirinya mencakup ranah diri, keluarga, teman sebaya, dan sekolah (Huebner, 2001). Sebagai contoh, kepuasan siswa remaja yang tinggi dalam ranah keluarga dan ranah sekolah ditemukan dapat mengurangi kenakalan berkelompok (Whitley, 2010). Selain itu, kepuasan remaja yang tinggi dalam ranah keluarga dan ranah teman sebaya ditemukan sangat berperan dalam meningkatkan kemampuan adaptasi remaja terhadap lingkungan (Huebner, 1994). Sebaliknya, kepuasan hidup remaja secara global yang rendah, ditemukan dapat meningkatkan externalizing problems (seperti tindakan agresi, impulsif, dan suka menentang), dan internalizing problems (seperti depresi, kecemasan, dan tindak bunuh diri) pada remaja (Haranin, Huebner, \& Suldo, 2007; Suldo \& Huebner, 2006; Suldo \& Huebner, 2004). Maka dari itu, dapat dikatakan bahwa kepuasan 
hidup yang positif dapat membantu siswa untuk berkembang secara positif, sehingga secara tidak langsung akan membantu siswa yang berada pada masa remaja untuk siap memasuki masa dewasa.

Pada umumnya siswa banyak menghabiskan waktu untuk beraktivitas di sekolah. Selama berada di sekolah, siswa melakukan kegiatan yang bersifat akademis, seperti belajar, mengerjakan tugas sekolah, dan mengikuti ujian sekolah. Kegiatan yang bersifat akademis ini merupakan kegiatan utama dalam sekolah, karena sekolah bertujuan untuk dapat meningkatkan kemampuan akademis siswa. Meskipun demikian, sebagai institusi yang menjembatani masa kanak-kanak dan masa dewasa, sekolah seharusnya tidak hanya berfokus pada peningkatan kemampuan akademis siswa, tetapi juga pada perkembangan diri siswa. Sekolah sebaiknya dapat berperan dalam melindungi siswa dari masalah-masalah perilaku. Oleh karena itu, penelitian ini mencoba mencari tahu seberapa besar kontribusi faktor-faktor bersifat akademis terhadap kepuasan hidup siswa.

Terdapat beberapa faktor akademis yang ditemukan mempengaruhi kepuasan hidup siswa. Suldo, Riley, dan Shaffer (2006), menyatakan bahwa kecerdasan, pencapaian akademis, dan academic self-efficacy memiliki korelasi dengan kepuasan hidup siswa. Selanjutnya juga ditemukan variabel lain yang berkorelasi dengan kepuasan hidup siswa, yaitu dukungan guru dan iklim sekolah (Suldo, Riley, \& Shaffer, 2006; Suldo, Shaffer, \& Riley, 2008).

Dari seluruh faktor akademis di atas, academic self-efficacy ditemukan memiliki konsistensi yang baik dalam berkorelasi dengan kepuasan hidup, baik bagi anak-anak maupun remaja di Amerika (Huebner, Gilman, \& Laughlin, dalam Suldo, Riley, \& Shaffer, 2006). Hasil penelitian Huebner, Gilman, dan Laughlin (dalam Suldo, Riley, \& Shaffer, 2006), menunjukkan bahwa siswa yang memiliki tingkat kepuasan hidup yang lebih tinggi secara signifikan dibandingkan teman-teman sebayanya, juga memiliki academic self-efficacy yang lebih tinggi dibandingkan siswa lain yang tingkat kepuasan hidupnya lebih rendah. Hasil yang serupa ditemukan juga pada responden siswa di Cina (Leung, McBride-Chang, \& Lai, dalam Suldo, Riley, \& Shaffer, 2006). Hasil korelasi antara kedua variabel ini lebih konsisten daripada korelasi antara kecerdasan maupun pencapaian akademis dengan kepuasan hidup (Suldo, Riley, \& Shaffer, 2006), sehingga dapat dikatakan bahwa academic self-efficacy merupakan variabel yang baik untuk memprediksi kepuasan hidup siswa. Walaupun sudah diketahui korelasi dari academic self-efficacy dengan kepuasan hidup siswa, namun belum ditemukan seberapa besar kontribusi academic self-efficacy terhadap kepuasan hidup siswa, terutama bagi siswa di Indonesia.

Selain itu, dukungan guru juga ditemukan berkorelasi dengan kepuasan hidup siswa, walaupun hasilnya bervariasi tergantung pada budaya di daerah yang diteliti (Suldo, Riley, \& Shaffer, 2006). Walaupun cukup banyak penelitian yang meneliti korelasi antara dukungan guru dengan kepuasan hidup siswa, variabel ini hanyalah merupakan satu bagian kecil dari variabel yang lebih besar, yaitu iklim sekolah (Brand, Felner, Shim, Seitsinger, \& Dumas, 2003). Sebaliknya, penelitian mengenai korelasi iklim sekolah terhadap kepuasan hidup siswa masih tergolong sedikit (Suldo, Riley, \& Shaffer, 2006). Dari penelitian Suldo, ThaljiRaitano, Hasemeyer, Gelley, dan Hoy (2012), ditemukan bahwa iklim sekolah berkorelasi positif dengan kepuasan hidup siswa. Artinya, siswa yang mempersepsikan iklim sekolahnya positif, merasakan kepuasan hidup lebih tinggi dibandingkan siswa yang memiliki persepsi negatif terhadap sekolahnya. Hal ini mendukung hasil penelitian-penelitian sebelumnya mengenai manfaat iklim sekolah terhadap kemampuan penyesuaian diri siswa, sehingga siswa dapat terhindar dari masalah perilaku dan emosional (Loukas, Suzuki, \& Horton, 2006; Connell \& Ryan; Connell \& Wellborn; Eccles, Midgley, Buchanan, Wigfield, Reuman, \& Mac Iver, dalam Way, Reddy, \& Rhodes, 2007). Meskipun demikian, pada penelitian-penelitian tersebut belum dijelaskan bagaimana kontribusi iklim sekolah terhadap kepuasan hidup siswa. 
Berdasarkan latar belakang di atas, penelitian ini bermaksud untuk mencari tahu bagaimana kontribusi faktor akademis yang diwakili oleh variabel academic self-efficacy dan iklim sekolah terhadap kepuasan hidup siswa. Sebagaimana yang telah diuraikan sebelumnya, faktor akademis diketahui berkaitan dengan aktivitas utama siswa di sekolah, sehingga memiliki peran yang penting bagi kepuasan hidup siswa. Terlepas dari hal tersebut, jumlah literatur yang membahas kontribusi faktor akademis terhadap kepuasan hidup siswa masih sedikit (Suldo, Shaffer, \& Riley, 2008).

Selain itu penelitian ini juga bermaksud untuk mengetahui perbedaan penilaian kepuasan hidup antara responden perempuan dan laki-laki. Siswa remaja perempuan diketahui lebih mudah merasakan ketidakpuasan terhadap dirinya, misalnya karena khawatir terhadap bentuk tubuhnya, berbeda dengan siswa laki-laki yang semakin puas dengan bentuk tubuhnya yang semakin berotot (Feingold \& Mazella, dalam Papalia, Olds, \& Feldman, 2009). Siswa remaja perempuan juga ditemukan lebih mudah mengalami depresi (Brent \& Birmaher, dalam Papalia, Olds, \& Feldman, 2009) dan lebih rentan terhadap stres akibat hubungan sosial $(\mathrm{Ge}$ dkk., dalam Papalia, Olds, \& Feldman, 2009). Berdasarkan penjelasan tersebut, maka peneliti menduga akan menemukan perbedaan penilaian kepuasan hidup pada siswa perempuan dan lakilaki. Jika memang benar demikian, maka dalam upaya membentuk kepuasan hidup yang baik bagi siswa, siswa perempuan harus mendapatkan perhatian yang lebih khusus.

Dalam penelitian ini, responden yang diambil adalah siswa remaja yang bersekolah pada tingkat pendidikan menengah, yaitu kelas XII SMA. Chow (2008), menggambarkan lingkungan SMA sebagai lingkungan sekolah yang memiliki metode belajar yang lebih kaku, dukungan emosional dan instruksional dari guru yang lebih sedikit, dan penekanan terhadap prestasi akademis yang lebih tinggi dibandingkan pada jenjang-jenjang pendidikan sebelumnya. Lingkungan SMA juga dinilai sebagai lingkungan yang mengekspos remaja pada tekanan sosial yang sangat besar untuk terlibat dalam perbuatan antisosial dan tekanan teman sebaya yang lebih intens (Barber \& Olson; Isakson \& Javis; Seidman \& French, dalam Chow, 2008). Dalam penelitian yang dilakukan selama tiga tahun pada siswa yang duduk di kelas enam hingga mencapai kelas delapan, Way, Reddy, dan Rhodes (2007) menemukan bahwa seiring bertambahnya tingkat pendidikan, persepsi siswa akan iklim sekolahnya menjadi lebih negatif. Siswa melaporkan peningkatan gejala depresi, perilaku bermasalah, dan penurunan self-esteem selama tiga tahun tersebut yang secara tidak langsung menunjukkan penurunan tingkat kepuasan hidup (Way, Reddy, \& Rhodes, 2007). Atas dasar inilah maka diperkirakan penurunan tingkat kepuasan hidup akan terus terjadi hingga ke tingkat SMA, sehingga penelitian kepuasan hidup yang melibatkan siswa SMA menjadi penting untuk dilakukan.

Berdasarkan latar belakang di atas, rumusan masalah pada penelitian ini adalah:

1. Adakah kontribusi signifikan dari variabel academic self-efficacy dan iklim sekolah secara bersama-sama terhadap kepuasan hidup siswa SMA?

2. Adakah kontribusi bermakna dari variabel academic self-efficacy terhadap kepuasan hidup siswa SMA?

3. Adakah kontribusi bermakna dari variabel iklim sekolah terhadap kepuasan hidup siswa SMA?

4. Adakah perbedaan kepuasan hidup antara responden perempuan dan laki-laki?

Hipotesis penelitian berdasarkan rumusan masalah di atas adalah:

H1: Secara bersama-sama, variabel academic self-efficacy dan iklim sekolah memberikan kontribusi bermakna terhadap kepuasan hidup siswa SMA.

$\mathrm{H} 2$ : Secara masing-masing, variabel academic self-efficacy memberikan kontribusi bermakna terhadap kepuasan hidup siswa SMA.

H3: Secara masing-masing, variabel iklim sekolah memberikan kontribusi bermakna terhadap kepuasan hidup siswa SMA. 
H4: Terdapat perbedaan yang signifikan pada penilaian variabel kepuasan hidup antara responden perempuan dan laki-laki.
Adapun berikut model kerangka konseptual pada penelitian ini:

\section{Gambar 1. Kerangka Konseptual}

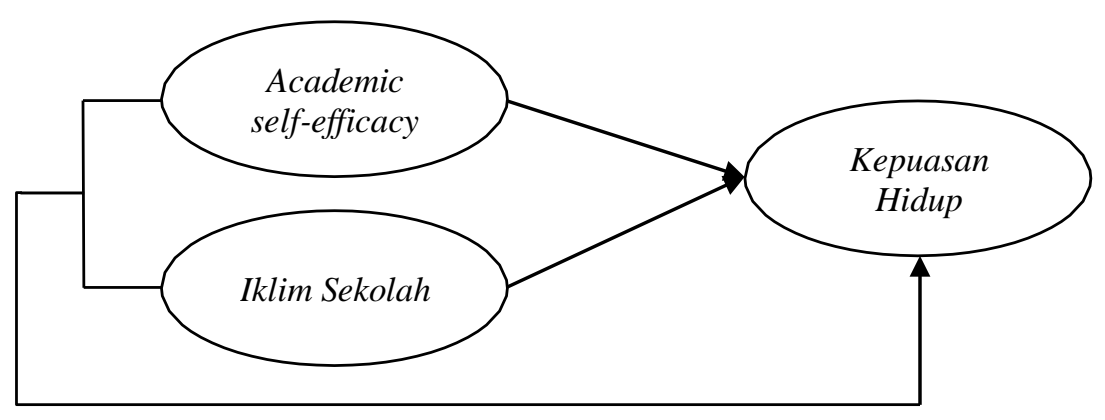

\section{METODE}

Responden penelitian. Populasi pada penelitian ini adalah seluruh siswa remaja perempuan dan laki-laki yang berasal dari SMA Negeri di kota Depok yang bukan merupakan sekolah berstatus unggulan atau RSBI (Rintisan Sekolah Bertaraf Internasional) maupun SBI (Sekolah Bertaraf Internasional).

Hal ini dimaksudkan untuk memperoleh karakteristik siswa yang lebih beragam sehingga hasil penelitian dapat digeneralisasi pada populasi yang serupa. Dari karakteristik populasi tersebut diperoleh lima sekolah yang memenuhi kualifikasi, yaitu SMAN 4, SMAN 5, SMAN 6, SMAN 7, dan SMAN 8 Depok.

Responden pada penelitian ini memiliki karakteristik sebagai berikut: (1) perempuan atau laki-laki; (2) telah duduk di kelas XII; dan (3) berasal dari kelas IPA (Ilmu Pengetahuan Alam) atau IPS (Ilmu Pengetahuan Sosial). Siswa kelas XII dipilih menjadi responden dalam penelitian ini dikarenakan iklim sekolah yang merupakan salah satu variabel yang diteliti lebih tepat jika diukur oleh siswa yang sudah cukup lama berada di sekolah. Agar didapatkan data yang lebih akurat, maka siswa kelas XII dipilih sebagai responden penelitian. Dari ketentuan karakteristik responden tersebut diperoleh hanya empat sekolah yang memenuhi kualifikasi, yaitu SMAN 4, SMAN 5, SMAN 6, dan SMAN 7 Depok. SMAN 8 Depok tidak memenuhi kualifikasi karena belum memiliki siswa kelas XII saat penelitian dilakukan.

Dari keempat sekolah tersebut, siswa dari SMAN 4 Depok dilibatkan pada tahap uji coba, sementara tiga SMAN sisanya menjadi peserta pada tahap pelaksanaan. Jumlah akhir responden penelitian adalah 221 siswa yang diperoleh dengan metode accidental sampling.

Desain penelitian. Pada penelitian ini peneliti menggunakan metode kuantitatif. Metode penelitian kuantitatif digunakan karena penelitian ini memiliki ciri-ciri yang sesuai dengan metode kuantitatif, yaitu: (1) rancangannya terstruktur, formal, spesifik, dan terperinci; (2) data yang dikumpulkan dapat dikuantifikasi atau dihitung;

(3) rentang waktu penelitian pada umumnya pendek; (4) membutuhkan hipotesis yang perlu dijawab; dan (5) analisis data menggunakan perhitungan statistik (Yusuf, 2016).

Instrumen penelitian. Dalam mengumpulkan data, metode yang digunakan adalah dengan menggunakan kuesioner. Kuesioner dipilih karena merupakan metode yang cocok untuk penelitian dengan jumlah sampel yang besar dan tersebar di area geografis yang luas (Kumar, 2005). Metode kuesioner umumnya digunakan pada responden berjumlah banyak sehingga penggunaan metode ini memiliki keunggulan tersendiri disamping metode-metode lainnya, yaitu dapat menggeneralisir hasil penelitian yang diperoleh. 
Pada penelitian ini terdapat dua jenis variabel, yaitu variabel bebas dan variabel terikat. Variabel terikat (DV) pada penelitian ini adalah kepuasan hidup, sementara variabel bebasnya adalah academic self-efficacy (IV1) dan iklim sekolah (IV2).

Definisi operasional kepuasan hidup adalah skor yang diperoleh dari alat ukur kepuasan hidup siswa. Alat ukur yang digunakan merupakan modifikasi dari alat ukur kepuasan hidup remaja yang dibuat oleh Amalia (2007), yang berlandaskan atas teori Papalia, Olds, dan Feldman (dalam Amalia, 2007), dan Multidimensional Student Life Satisfaction Scale (Huebner, 2001). Dimensi yang digunakan dalam alat ukur baru ini adalah dimensi diri, keluarga, teman, dan sekolah. Semakin tinggi skor yang dimiliki responden pada alat ukur ini, menunjukkan bahwa responden semakin puas terhadap kehidupannya secara menyeluruh, demikian juga sebaliknya.

Definisi operasional variabel academic self-efficacy adalah skor yang diperoleh dari alat ukur academic self-efficacy. Alat ukur ini merupakan alat ukur baru yang mengacu pada dimensi academic self-efficacy dari Jinks dan Morgan (1997), yaitu bakat, usaha, dan konteks. Semakin tinggi skor pada alat ukur ini, menunjukkan bahwa responden semakin yakin bahwa dia memiliki kemampuan akademis yang baik sehingga lebih berani menghadapi tantangan akademis yang memiliki tingkat kesulitan yang lebih tinggi.

Definisi operasional variabel iklim sekolah adalah skor yang diperoleh dari alat ukur iklim sekolah yang merupakan hasil modifikasi dari alat ukur iklim sekolah untuk siswa sekolah menengah dari Brand, Felner, Shim, Seitsinger, dan Dumas (2003). Pada alat ukur aslinya, terdapat 10 dimensi untuk mengukur iklim sekolah. Pada penelitian ini, dua dimensi yang peneliti anggap masih mengukur hal yang sama dilebur menjadi satu dimensi, sehingga terdapat sembilan dimensi iklim sekolah yang digunakan pada penelitian ini. Kesembilan dimensi tersebut adalah dukungan guru, interaksi dengan teman sebaya, masukan siswa dalam pengambilan keputusan, konsistensi dan kejelasan aturan, kekerasan dalam disiplin, komitmen siswa/orientasi pencapaian, inovasi dan relevansi dari instruksi pengajaran, dukungan terhadap keberagaman, dan keamanan sekolah. Semakin tinggi skor dari alat ukur iklim sekolah berarti responden mempersepsikan iklim sekolahnya semakin positif, demikian juga sebaliknya.

Prosedur penelitian. Penelitian ini terdiri dari tahap persiapan, uji coba alat ukur, pelaksanaan, dan tahap akhir. Pada tahap persiapan, ditentukan populasi dan sampel dari penelitian serta alat ukur yang akan digunakan. Pada tahap uji coba, alat ukur yang sudah dipersiapkan akan diuji validitas dan reliabilitasnya lalu dikoreksi bila diperlukan. Kemudian pada tahap pelaksanaan, alat ukur yang baru digunakan sebagai instrumen penelitian terhadap target responden. Terakhir, pada tahap akhir seluruh data yang berhasil dikumpulkan dievaluasi dan hasilnya dituliskan dalam bentuk laporan.

Teknik analisis. Sebelum data diolah, peneliti membalik skor pada item unfavorable atau item berkonotasi negatif: skor 1 diubah menjadi skor 6, skor 2 diubah menjadi skor 5, skor 3 diubah menjadi skor 4, dan sebaliknya. Total skor per variabel dijumlahkan untuk kemudian digunakan pada pengolahan data lebih lanjut. Untuk membuktikan hipotesis pertama, kedua, dan ketiga, digunakan uji linear berganda. Uji regresi linear berganda dilakukan untuk melihat pengaruh dan besar kontribusi antara lebih dari satu variabel independen terhadap satu variabel dependen (Priyatno, 2009). Kontribusi variabel independen terhadap variabel dependen secara bersama-sama dilihat dari nilai $\mathrm{R}^{2}$ pada tabel $\mathrm{F}$ (ANOVA), sementara kontribusi secara masingmasing dilihat dari nilai $\beta$ pada tabel t. Masingmasing nilai tersebut selanjutnya diubah ke dalam bentuk persentase dengan menggunakan rumus koefisien determinasi (Sarwono, 2010). Hasil yang diperoleh dari pengolahan data inilah yang digunakan untuk membuktikan hipotesis pertama, kedua, dan ketiga.

Selain itu juga dicari tahu perbedaan nilai variabel kepuasan sekolah berdasarkan jenis kelamin. Jenis kelamin memiliki dua kelompok 
populasi, yaitu perempuan dan laki-laki. Maka digunakan uji $\mathrm{t}$ independen untuk mengetahui perbandingan nilai rata-rata populasi pada kedua kelompok tersebut. Hasil yang diperoleh dari pengolahan data ini digunakan untuk membuktikan hipotesis keempat.

\section{HASIL}

Gambaran umum dari responden penelitian ditampilkan pada Tabel 1, Tabel 2, dan Tabel 3 secara berurutan berdasarkan karakteristik jenis kelamin, jurusan, dan asal sekolah.

Tabel 1. Karakteristik Responden Berdasarkan Jenis Kelamin

\begin{tabular}{lll}
\hline Jenis Kelamin & $\begin{array}{l}\text { Jumlah } \\
\text { Responden }\end{array}$ & Persentase \\
\cline { 2 - 2 } Perempuan & 126 & $57,01 \%$ \\
Laki-laki & 95 & $42,99 \%$ \\
\hline Total & 221 & $100,00 \%$ \\
\hline
\end{tabular}

Pada Tabel 1 ditampilkan data responden berdasarkan jenis kelamin. Responden berjenis kelamin perempuan berjumlah lebih banyak daripada responden laki-laki. Dari total responden yang berjumlah 221 orang, 126 orang responden berjenis kelamin perempuan $(57,01 \%)$, sementara responden berjenis kelamin laki-laki sebanyak 95 orang $(42,99 \%)$.

Tabel 2. Karakteristik Responden

\begin{tabular}{lll} 
& \multicolumn{2}{c}{ Berdasarkan Jurusan } \\
\hline Jumlah & Persentase \\
& \multicolumn{2}{c}{ Responden } \\
& 115 & $52,04 \%$ \\
IPA & 106 & $47,96 \%$ \\
\hline TPS & 221 & $100 \%$ \\
\hline
\end{tabular}

Tabel 2 menampilkan data responden berdasarkan jurusan. Terdapat dua jurusan pada setiap sekolah, yaitu Ilmu Pengetahuan Alam (IPA) dan Ilmu Pengetahuan Sosial (IPS). Dari total 221 responden, terdapat 115 responden yang berasal dari jurusan IPA $(52,04 \%)$, sementara 106 responden $(47,96 \%)$ berasal dari jurusan IPS.
Tabel 3. Karakteristik Responden Berdasarkan Asal Sekolah

\begin{tabular}{lll}
\hline Asal Sekolah & $\begin{array}{l}\text { Jumlah } \\
\text { Responden }\end{array}$ & Persentase \\
\cline { 2 - 2 } SMAN 5 & 80 & $36,20 \%$ \\
SMAN 6 & 69 & $31,22 \%$ \\
SMAN 7 & 72 & $32,58 \%$ \\
\hline Total & 221 & $100,00 \%$ \\
\hline
\end{tabular}

Tabel 3 menampilkan data responden berdasarkan asal sekolah. Dari keseluruhan responden yang berjumlah 221 orang, 80 responden $(36,20 \%)$ berasal dari SMAN 5, 69 responden $(32,58 \%)$ dari SMAN 7, dan 72 responden $(31,22 \%)$ dari SMAN 6 Depok.

Fokus utama dalam penelitian ini adalah mengetahui kaitan antara variabel academic selfefficacy dan iklim sekolah sebagai dua variabel independen dengan kepuasan hidup sebagai variabel dependen. Untuk itu, analisis dimulai dengan deskripsi dari masing-masing variabel, kemudian dilanjutkan dengan analisis kaitan antar variabel yang dilengkapi dengan analisis besaran kontribusi variabel independen terhadap variabel dependen dengan menggunakan metode regresi.

Data deskriptif yang ditampilkan adalah nilai minimum, nilai maksimum, nilai rata-rata, dan standar deviasi (SD). Data tersebut dapat dilihat pada tabel 4 berikut.

Tabel 4. Gambaran Deskriptif Variabel

\begin{tabular}{|c|c|c|c|c|}
\hline \multicolumn{5}{|c|}{ Penelitian } \\
\hline \multicolumn{2}{|c|}{ Variabel Min Maks } & ${ }_{\text {Rata- }}^{\text {SD }}$ & Rata & \\
\hline Kepuasan & 73,00 & 144,00 & 112,65 & 11,537 \\
\hline Hidup & & & & \\
\hline $\begin{array}{l}\text { Academic } \\
\text { Self- } \\
\text { Efficacy }\end{array}$ & 50,00 & 115,00 & 89,82 & 11,373 \\
\hline $\begin{array}{l}\text { Iklim } \\
\text { Sekolah }\end{array}$ & 100,00 & 181,00 & 144,40 & 14,189 \\
\hline
\end{tabular}

Selanjutnya dapat dilihat sebaran total skor reponden pada Tabel 5 untuk variabel kepuasan hidup, Tabel 6 untuk variabel academic self-efficacy, dan Tabel 7 untuk variabel iklim sekolah. Pengategorian sebaran dibagi menjadi 3, yaitu rendah, sedang, dan tinggi. Untuk 
menentukan kategori, digunakan nilai rata-rata dan nilai standar deviasi. Kategori rendah diperoleh dari nilai skor total responden yang berada di bawah nilai rata-rata dikurangi standar deviasi; kategori tinggi diperoleh dari nilai skor total responden yang berada di atas nilai rata-rata ditambah standar deviasi; sedangkan kategori sedang berada di antara keduanya.

Tabel 5. Sebaran Skor Total Variabel Kepuasan Hidup

\begin{tabular}{lcc}
\hline Kategori & Jumlah Responden & Persentase \\
\hline Rendah & 33 & $14,93 \%$ \\
Sedang & 156 & $70,59 \%$ \\
Tinggi & 32 & $14,48 \%$ \\
\hline Total & $\mathbf{2 2 1}$ & $\mathbf{1 0 0 , 0 0 \%}$ \\
\hline
\end{tabular}

Tabel 5 menggambarkan sebaran skor total pada variabel kepuasan hidup sebagaimana dinilai oleh para responden siswa SMAN 5, SMAN 6, dan SMAN 7 Depok. Dari tabel dapat dilihat bahwa terdapat 156 responden $(70,59 \%)$ berada di kategori sedang pada variabel kepuasan hidup.

Tabel 6. Sebaran Skor Total Variabel Academic Self-Efficacy

\begin{tabular}{lcc}
\hline Kategori & Jumlah Responden & Persentase \\
\hline Rendah & 35 & $15,84 \%$ \\
Sedang & 153 & $69,23 \%$ \\
Tinggi & 33 & $14,93 \%$ \\
\hline Total & $\mathbf{2 2 1}$ & $\mathbf{1 0 0 , 0 0 \%}$ \\
\hline
\end{tabular}

Tabel 6 di atas menggambarkan sebaran skor total pada variabel academic self-efficacy sebagaimana yang dinilai oleh para responden siswa SMAN 5, SMAN 6, dan SMAN 7 Depok. Dari tabel dapat dilihat bahwa untuk kategori sedang pada variabel academic self-efficacy ini terdapat $69,23 \%$ responden.

Tabel 7. Sebaran Skor Total Variabel Iklim Sekolah

\begin{tabular}{lcc}
\hline Kategori & Jumlah Responden & Persentase \\
\hline Rendah & 35 & $15,84 \%$ \\
Sedang & 154 & $69,68 \%$ \\
Tinggi & 32 & $14,48 \%$ \\
\hline Total & $\mathbf{2 2 1}$ & $\mathbf{1 0 0 , 0 0 \%}$ \\
\hline
\end{tabular}

Tabel 7 menggambarkan sebaran skor total pada variabel iklim sekolah sebagaimana yang dinilai oleh para responden siswa SMAN 5, SMAN 6,dan SMAN 7 Depok. Dari tabel dapat dilihat bahwa untuk kategori sedang pada variabel iklim sekolah ini terdapat 69,68\% responden.

Selanjutnya untuk membuktikan hipotesis pertama, kedua, dan ketiga dilakukan perhitungan regresi linear berganda yang hasilnya ditampilkan pada Tabel 8 dan Tabel 9 . Sementara itu, untuk membuktikan hipotesis keempat dilakukan perhitungan uji $\mathrm{t}$ independen yang hasilnya ditampilkan pada Tabel 10 .

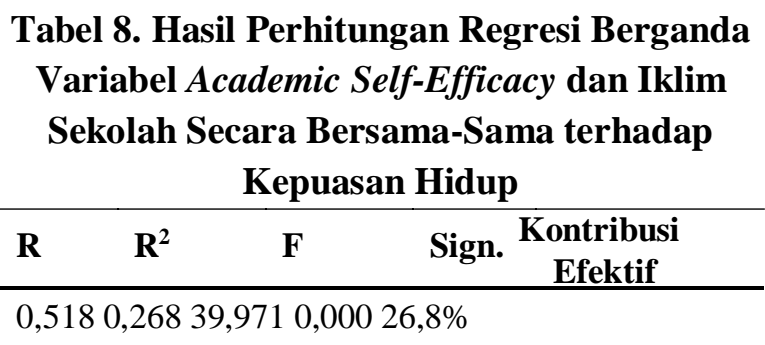

Tabel 8 menunjukkan hasil dari pengujian regresi berganda pada variabel academic selfefficacy dan iklim sekolah secara bersama-sama terhadap kepuasan hidup. Pada tabel tersebut tampak $\mathrm{R}^{2}=.268, \mathrm{~F}=39,97, p=.000$. Hal tersebut berarti $\mathrm{R}^{2}$ signifikan, karena $p<.05$. Dari data tersebut dapat diartikan bahwa terdapat pengaruh dari variabel academic self-efficacy dan iklim sekolah secara bersama-sama terhadap variabel kepuasan hidup. Artinya, bervariasinya nilai kepuasan hidup siswa dipengaruhi dengan variansi nilai academic selfefficacy dan iklim sekolah.

Selanjutnya dari data yang sudah tersedia dapat diketahui kontribusi variabel independen terhadap variabel dependen. Untuk mengetahui kontribusi variabel academic self-efficacy dan iklim sekolah secara simultan terhadap variabel kepuasan hidup, digunakan nilai $\mathrm{R}^{2}$. Nilai $\mathrm{R}^{2}=$ 0,268, dengan demikian diperoleh besar kontribusi variabel academic self-efficacy dan iklim sekolah secara bersama-sama terhadap kepuasan hidup sebesar 26,8\%. Dapat dikatakan bahwa variansi dari nilai kepuasan hidup dipengaruhi sebesar $26,8 \%$ oleh academic self- 
efficacy dan iklim sekolah, sedangkan sisanya yakni sebesar $73,2 \%$ dipengaruhi oleh variabel lain selain dari kedua variabel yang diteliti ini.

\begin{tabular}{|c|c|c|c|}
\hline \multicolumn{4}{|c|}{$\begin{array}{l}\text { Tabel 9. Hasil Perhitungan Regresi Berganda } \\
\text { dari Variabel Academic Self-Efficacy dan } \\
\text { Iklim Sekolah Secara Masing-masing dengan } \\
\text { Kepuasan Hidup }\end{array}$} \\
\hline Variabel & $\mathbf{t}$ & B & Sign. \\
\hline Academic self-efficacy & 3,302 & 0,212 & 0,001 \\
\hline Iklim sekolah & \multicolumn{3}{|c|}{$6,0480,3890,0 C 0$} \\
\hline
\end{tabular}

Tabel 9 menunjukkan hasil uji regresi berganda dari variabel academic self-efficacy dan iklim sekolah secara masing-masing dengan kepuasan hidup. Untuk variabel academic selfefficacy, dari tabel di atas diketahui bahwa nilai $\mathrm{t}$ $=3,302, p=.001$. Hal tersebut berarti terdapat kontribusi yang signifikan atau bermakna dari variabel academic self-efficacy terhadap kepuasan hidup. Besar kontribusi bermakna dari variabel tersebut dapat dilihat dari nilai $\beta=.212$. Maka diperoleh kontribusi academic self-efficacy terhadap kepuasan hidup sebesar 21,2\%.

Untuk variabel iklim sekolah, diperoleh nilai $\mathrm{t}=6,048, p=.000$. Maka dapat diartikan bahwa terdapat kontribusi yang signifikan atau bermakna dari variabel iklim sekolah terhadap kepuasan hidup. Besar kontribusi bermakna dari variabel tersebut dapat dilihat dari nilai $\beta=.389$. Maka diperoleh kontribusi iklim sekolah terhadap kepuasan hidup sebesar 38,9\%.

\begin{tabular}{|c|c|c|c|c|}
\hline \multicolumn{5}{|c|}{$\begin{array}{l}\text { Tabel 10. Perbandingan Kepuasan Hidup } \\
\text { Responden Berdasarkan Jenis Kelamin }\end{array}$} \\
\hline Variabel & $\begin{array}{l}\text { Jenis } \\
\text { Kelamin }\end{array}$ & $\mathbf{N}$ & $\begin{array}{l}\text { Rata- } \\
\text { Rata }\end{array}$ & Sign. \\
\hline hidup & $\begin{array}{l}\text { Perempuan } \\
\text { Laki-laki }\end{array}$ & $\begin{array}{l}126 \\
95\end{array}$ & $\begin{array}{l}4,1864 \\
4,1532\end{array}$ & $\begin{array}{l}\mathrm{t}=0,553 \\
\mathrm{p}=0,290\end{array}$ \\
\hline
\end{tabular}

Tabel 10 menggambarkan hasil uji $\mathrm{t}$ independen untuk mengetahui perbandingan nilai rata-rata variabel kepuasan hidup berdasarkan jenis kelamin responden. Dari hasil perhitungan diperoleh nilai $\mathrm{t}=.553, p=.29$. Hal ini menunjukkan bahwa rata-rata nilai kepuasan hidup responden perempuan tidak berbeda secara signifikan dengan rata-rata responden laki-laki.

\section{SIMPULAN}

Berdasarkan hasil olah data yang telah dilakukan, berikut kesimpulan yang dapat ditarik terkait dengan hipotesis penelitian:

a) H1 yang berbunyi: "Secara bersama-sama, variabel academic self-efficacy dan iklim sekolah memberikan kontribusi bermakna terhadap kepuasan hidup siswa SMA," terbukti secara signifikan.

b) H2 yang berbunyi: "Secara masing-masing, variabel academic self-efficacy memberikan kontribusi bermakna terhadap kepuasan hidup siswa SMA," terbukti secara signifikan.

c) H3 yang berbunyi: "Secara masing-masing, variabel iklim sekolah memberikan kontribusi bermakna terhadap kepuasan hidup siswa SMA," terbukti secara signifikan.

d) H4 yang berbunyi: "Terdapat perbedaan yang signifikan pada penilaian variabel kepuasan hidup antara responden perempuan dan lakilaki," tidak terbukti signifikan.

\section{DISKUSI}

Penting untuk diketahui hal apa saja yang berkaitan dengan kepuasan hidup siswa remaja. Semakin banyak informasi yang didapatkan mengenai hal ini, semakin banyak pula cara yang bisa dikembangkan oleh guru untuk menciptakan suasana belajar yang bukan hanya mendorong siswa untuk berprestasi, tetapi juga memperhatikan kepuasan hidup mereka. Identifikasi dini pada diri siswa dan bagaimana siswa dapat belajar dengan lebih baik tentu dapat mengarah pada optimalisasi kualitas hidup siswa remaja, yaitu pada kesehatan dan kesejahteraan fisik, dan psikologisnya, serta pada kebahagiaannya (Dwyer, 2008).

Penelitian ini membuktikan bahwa variabel yang bersifat akademis, yaitu academic self-efficacy dan iklim sekolah, memiliki kontribusi terhadap kepuasan hidup siswa SMA. Siswa yang menghabiskan banyak waktunya untuk beraktivitas di sekolah dapat merasakan bahwa sekolah seperti rumah keduanya, sehingga pengalaman-pengalaman yang dialami di sekolah 
dapat mempengaruhi penilaiannya terhadap hidup. Hal ini mendukung penelititan sebelumnya yang dilakukan oleh Suldo, Shaffer, dan Riley (2008), yang menyatakan bahwa kepuasan hidup siswa remaja dipengaruhi oleh faktor-faktor yang bersifat akademis. Oleh karena itu, faktor akademis khususnya academic self-efficacy dan iklim sekolah, perlu diperhatikan untuk dapat membentuk kepuasan hidup siswa SMA yang positif.

Besar kontribusi dari variabel academic self-efficacy dan iklim sekolah secara bersamasama terhadap kepuasan hidup sebesar $26,8 \%$. Dari nilai ini, diketahui bahwa terdapat $73,2 \%$ kontribusi dari faktor lain yang tidak diteliti terhadap kepuasan hidup siswa. Kemungkinan faktor lain yang memberikan kontribusi terhadap kepuasan hidup ini antara lain: (1) berasal dari faktor akademis lain seperti pencapaian akademis, kecerdasan, dan kepuasan sekolah; (2) berasal dari faktor non-akademis, seperti faktor demografis atau hal yang terkait dengan keluarga. Untuk mengetahui bagaimana kontribusi dari faktor-faktor tersebut, dibutuhkan penelitian lebih lanjut.

Hasil penelitian menyatakan bahwa variabel academic self-efficacy memiliki kontribusi bermakna terhadap kepuasan hidup. Hal ini menunjukkan bahwa untuk meningkatkan kepuasan hidup siswa remaja, diperlukan perhatian pada academic self-efficacy siswa. Siswa perlu merasa yakin dan percaya diri akan kemampuan akademisnya. Sebagaimana sifat remaja yang mulai memperhatikan prestasi dan kemampuan dirinya, maka wajar jika seorang siswa remaja merasa yakin pada kemampuan akademisnya, dia juga akan merasa lebih puas terhadap hidupnya. Sebaliknya, remaja yang meragukan kemampuan akademisnya, memiliki kemungkinan yang besar untuk merasa tidak puas terhadap kehidupannya. Perasaan mampu ini bisa mempengaruhi pikiran dan perasaan siswa sehingga dia akan terdorong untuk berperilaku sebagaimana yang ia pikirkan dan rasakan tentang dirinya. Keyakinan akan kemampuan diri siswa dapat mengalahkan kemampuan sebenarnya dalam diri seorang siswa. Bisa jadi siswa yang sebenarnya tidak memiliki nilai yang bagus pada pelajaran bahasa Inggris, tetapi meyakini bahwa dia bisa menguasai bahasa tersebut, akan terdorong untuk terus melatih kemampuan bahasa Inggrisnya. Pada akhirnya siswa tersebut bisa berbahasa Inggris dengan lancar sehingga dia merasa lebih puas pada dirinya. Kepuasan terhadap dirinya ini kemudian yang akan meningkatkan kepuasan hidup siswa tersebut. Hal ini dikuatkan dengan hasil penelitian terbaru bahwa siswa yang memiliki keyakinan yang tinggi akan targettarget akademisnya, menunjukkan kepuasan hidup yang juga tinggi (Singley, Lent, \& Sheu, 2011).

Hasil penelitian juga menunjukkan bahwa iklim sekolah memiliki kontribusi bermakna terhadap kepuasan hidup siswa. Siswa yang berada pada tahap masa remaja memiliki emosi yang masih belum matang. Sebagai remaja yang berada pada tahap peralihan menuju ke masa dewasa, banyak tuntutan yang diberikan kepada siswa dari lingkungan sosialnya. Terkadang tuntutan sosial ini saling bersinggungan dan dapat menimbulkan konflik sehingga membuat siswa kebingungan. Emosi yang tidak stabil ini dapat menimbulkan rasa tidak bahagia, sehingga sebagian siswa melampiaskannya dengan bertindak secara menyimpang, seperti berperilaku agresif, suka menentang, merasa kesepian, menutup diri dari dunia sosial, atau tidak peduli pada prestasi belajarnya (Thalib, 2010). Dari gambaran ini, dapat dilihat bahwa sebenarnya siswa remaja membutuhkan lingkungan yang dapat menerima dirinya apa adanya dan membantunya untuk dapat berperilaku secara positif dalam lingkungan sosial. Siswa membutuhkan lingkungan sekolah yang berisikan guru dan teman sebaya yang peduli dan suportif. Oleh karena itu, iklim sekolah yang positif dapat membantu siswa merasakan kepuasan hidup yang tinggi.

Berdasarkan perbandingan penilaian kepuasan hidup dari perbedaan jenis kelamin, penelitian ini tidak menemukan perbedaan nilai yang signifikan. Artinya, siswa perempuan dan laki-laki tidak memiliki perbedaan tingkat kepuasan hidup yang signifikan, hasil ini sesuai dengan penelitian Huebner (1991), Haranin, 
Huebner, \&Suldo (2007); Kapteyn, Smith, dan Van Soest (2009); dan Ng, Loy, Gudmunson, dan Cheong (2009). Siswa laki-laki bisa jadi memiliki hal-hal yang juga dicemaskan dalam hidupnya sebagaimana siswa perempuan. Mereka yang menjadi responden dari penelitian ini sedang berada pada tingkat akhir di bangku SMA. Di tahun terakhir SMA ini mereka tidak hanya akan menghadapi berbagai ujian di sekolah, tetapi juga diharapkan sudah mempersiapkan diri untuk menghadapi kehidupan pasca SMA, seperti meneruskan pendidikan atau memutuskan untuk bekerja. Maka, ketidakpuasan siswa perempuan terhadap dirinya sebagaimana dugaan sebelumnya mungkin menjadi tidak mendominasi responden perempuan pada penelitian ini. Walaupun demikian, tidak diketahui apakah perbedaan kelas responden mempengaruhi tingkat kepuasan hidup, karena siswa yang diteliti hanya siswa yang duduk di kelas XII. Dibutuhkan penelitian lebih lanjut untuk mengetahui apakah seiring bertambahnya tingkat pendidikan siswa, semakin bertambah juga ketidakpuasan hidup siswa.

Penelitian ini tidak terlepas dari beberapa keterbatasan. Pertama, kurang konsistennya penggunaan dimensi dengan definisi dari variabel. Hal ini terjadi pada variabel kepuasan hidup, definisi diambil dari teori Pavot, Diener, Colvin, dan Sandvik (dalam Danielsen, Samdal, Hetland, \& Wold, 2009), sementara dimensinya dirumuskan dari teori Papalia, Olds, dan Feldman (2009). Hal ini dikarenakan tidak ditemukannya pembahasan dimensi kepuasan hidup dari Pavot, Diener, Colvin, dan Sandvik (dalam Danielsen, Samdal, Hetland, \& Wold, 2009), sehingga untuk menentukan dimensinya perlu dicari sumber literatur lain. Sementara untuk variabel academic self-efficacy dan iklim sekolah, walaupun pencetus definisi dan penentu dimensinya adalah orang-orang yang berbeda, namun masih berlandaskan atas teori yang sama. Keterbatasan penelitian lainnya adalah penentuan dimensi pada variabel kepuasan hidup yang hanya membahas kehidupan remaja secara umum dan tidak membahas kepuasan hidup secara khusus. Dimensi tersebut diperoleh dengan merangkum aspek-aspek kehidupan mana saja yang sekiranya terdapat dalam kehidupan remaja.

\section{DAFTAR PUSTAKA}

Amalia, I. (2007). Penyusunan skala kepuasan hidup pada remaja. (Skripsi tidak dipublikasikan). Universitas Indonesia, Depok.

Brand, S., Felner, R., Shim, M., Seitsinger, M., \& Dumas, T. (2003). Middle school improvement and reform: Development and validation of a school-level assessment of climate, cultural pluralism, and school safety. Journal of Education Psychology, 95(3), 570-588.

Chow, H. P. H. (2008). The determinants of life satisfaction: High school students in Regina. The Alberta Journal of Educational Research, 54(4), 477-481.

Danielsen, A. G., Samdal, O., Hetland, J., \& Wold, B. (2009). School-related social support and students'perceived life satisfaction. The Journal of Educational Research, 102, 303-318.

Diener, E. (1994). Assessing subjective wellbeing: Progress and opportunities. Social Indicators Research, 31(2), 103-157.

Dwyer, M. (2008). Need for cognition, life satisfaction, and academic achievement. Epistimi, 3, 12-13.

Haranin, E. C., Huebner, E. S., \& Suldo, S. M. (2007). Predictive and incremental validity of global and domain-based adolescent life satisfaction reports. Journal of Psychoeducational Assessment, 25(2), 127-138.

Huebner, E. S. (1991). Correlates of life satisfaction in children. School Psychology Quarterly, 6 (2), 103-111.

Huebner, E. S. (1994). Preliminary development and validation of a multidimensional life satisfaction scale for children. Psychological Assessment, 6 (2), 149-158. 
Huebner, E. S. (2001). Multidimensional students' life satisfaction scale. Retrieved October, 26, 2011.

Huebner, E. S. (2004). Research on assessment of life satisfaction of children and adolescents. Social Indicators Research, 66(1), 3-33.

Jinks, J., \& Morgan, V. L. (1997). Students' sense of academic efficacy and achievement in science: A useful new direction for research regarding scientific literacy? Electronic Journal of Science Education, 1(2).

Kapteyn, A., Smith, J. P., \&Van Soest, A. (2009). Life satisfaction (Discussion Paper No. 4015). Retrieved from The Institute for the Study of Labor (IZA) website: http://ftp.iza.org/dp4015.pdf

Kumar, R. (2005). Research methodology: A step-by-step guide for beginners (2nd Ed.). London: Sage Publication.

Loukas, A., Suzuki, R., \& Horton, K. D. (2006). Examining school connectedness as a mediator of school climate effects. Journal of Research on Adolescence, 16(3), 491502.

Millie, A. (2009). Anti-social behavior. New York: Mc Graw Hill Open University Press.

Ng, K-M., Loy, J. T-C., Gudmunson, C. G., \& Cheong, W. (2009) Gender differences in marital and life satisfaction among Chinese Malaysians. Sex Roles, 60(1-2), 33-43.

Papalia, D. E., Olds, S. W., \& Feldman, R. D. (2009). Human development (11th Ed.). New York: McGraw-Hill.

Priyatno, D. (2009). SPSS: Untuk analisis korelasi, regresi, dan multivariate.Yogyakarta: Penerbit Gava Media.

Santrock, J. W. (2007). Adolescence (11th Ed.). New York: McGraw-Hill.

Sarwono, J. (2010). PASW statistik 18: Belajar statistik menjadi mudah dan cepat. Yogyakarta: CV Andi Offset.
Singley, D. B., Lent, R.W., \& Sheu, H-B. (2011). Longitudinal test of a social cognitive model of academic and life satisfaction. Journal of Career Assessment, 18(2), 133146.

Suldo, S. M., \& Huebner, E. S. (2004). Does life satisfaction moderate the effects of stressful life events on psychopathological behavior during adolescence? School Psychology Quarterly, 19(2), 93-105.

Suldo, S. M., \& Huebner, E. S. (2006). Is extremely high life satisfaction during adolescence advantageous? Social Indicators Research, 78, 179-203.

Suldo, S. M., Riley, K. N., \& Shaffer E. J. (2006). Academic correlates of children and adolescents' life satisfaction. School Psychology International, 27(5), 567-582.

Suldo, S. M., Shaffer E. J., \& Riley, K. N. (2008). A social-cognitive-behavioral model of academic predictors of adolescents' life satisfaction. School Psychology Quarterly, 22(1), 56-69.

Suldo, S. M., Thalji-Raitano, A., Hasemeyer, M., Gelley, C. D., \& Hoy, B. (2012). Understanding middle school student life satisfaction: Does school climate matter? [Abstract]. Applied Research in Quality of Life, 1-14.

Thalib, S. B. (2010). Psikologi pendidikan berbasis analisis empiris aplikatif. Jakarta: Kencana Prenada Media Group.

Way, N., Reddy, R., \& Rhodes, J. (2007) Students' perceptions of school climate during the middle school years: Associations with trajectories of psychological and behavioral adjustment. American Journal of Community Psychology, 40, 194- 213.

Whitley, A. M. (2010). Can kids be too happy in school? The optimal level of school satisfaction. (Doctoral dissertation). University of South Carolina, Columbia.

Yusuf, A. M. (2016). Metode penelitian: Kuantitatif, kualitatif, \& penelitian gabungan. Jakarta: Kencana. 